\title{
Streptococcal necrotising fasciitis: comparison between histological and clinical features
}

\author{
F G BARKER, * BARBARA J LEPPARD, $\dagger$ D V SEAL \\ From the *Department of Histopathology, Northwick Park Hospital, Harrow, Middlesex, the †Department of \\ Dermatology, University of Southampton, Royal South Hampshire Hospital, and the $\ddagger$ Division of \\ Communicable Diseases Clinical Research Centre, Harrow, Middlesex
}

SUMMARY Nineteen acute and 17 subacute cases of necrotising fasciitis due to $\beta$ haemolytic streptococci are described. Excised tissue from seven and four cases, respectively, was available for histological examination. The two clinical types showed remarkable similarities, with inflammation and necrosis from epidermis to subcutaneous fat. Haemorrhage was present in variable amounts in both types. Gram positive cocci were not always identified in tissue, nor cultured, when serological tests were required to confirm the diagnosis. The only apparent difference between the acute and subacute type was the higher incidence of thrombi in some blood vessels of acute cases, whereas patent vessels or recanalised thrombus were usually found in subacute cases. This quantitative difference in the degree of thrombosis may alone be responsible for the varying clinical features and response to antibiotics.

Necrotising fasciitis due to $\beta$ haemolytic streptococci (BHS) of Lancefield groups A (Streptococcus pyogenes), $\mathrm{C}$, and $\mathrm{G}$ has become more prevalent, particularly in elderly or diabetic patients. ${ }^{1}$ It usually arises as a community acquired infection, presenting clinically in an acute or subacute form, ${ }^{2}$ as opposed to that following surgery for abdominal sepsis which is often due to synergy between Bacteroides and coliform bacteria. ${ }^{3}$ Rarely, anaerobic streptococci cause fasciitis and streptococcal "gas gangrene." We investigated patients with acute and subacute types and attempted to distinguish the relevant histological features.

Acute infection with $S$ pyogenes can be fulminating, with early septicaemic death and disseminated intravascular coagulation, when only a small amount of localised necrotic tissue need be present. ${ }^{4-6}$ Alternatively, rapidly spreading tissue necrosis can occur after a trivial or inapparent injury, which usually follows the venous drainage above the fascial layer. This is called acute "necrotising fasciitis," although it is really a "necrotising suprafasciitis." This can also proceed to septicaemia and rapid death and must be managed surgically, as originally described by Meleney. ${ }^{7}$ It has been caused by BHS groups $\mathrm{A}, \mathrm{C}$, and $\mathrm{G}^{2}{ }^{\text {7-9 }}$

Spreading tissue inflammation can initially look

Accepted for publication 24 September 1986 like erysipelas or cellulitis. This may proceed to localised blistering, ulceration, and necrosis, but these patients have nearly always received antibiotics before this occurs. When the infections fails to resolve completely with antibiotics, necrosis of tissue overlying the fascial planes slowly develops, with the formation of a thick eschar that can take weeks or months to slough off. This is called subacute "necrotising fasciitis." These patients should also be managed surgically, but they rarely die. ${ }^{28}$ This type has previously been called "ulceration following cellulitis" 2 and is caused by BHS groups A and G. To make the diagnosis reliance was placed on serial antibody tests to streptolysin $\mathrm{O}$, deoxyribonuclease $\mathrm{B}$, and hyaluronidase (groups $\mathrm{A}$ and $\mathrm{C} / \mathrm{G}$ ), as described previously. ${ }^{8}$ This is because the open blistering lesions may not contain the streptococcus and are often contaminated with other bacteria.

\section{Patients and methods}

We have seen 21 patients with necrotising fasciitis in Southampton and 15 in Harrow over the past five years (tables 1 and 2). The histology of tissue excised from 11 of these patients was reviewed.

\section{HISTOLOGY}

Tissue was collected into formalin. Selected blocks were processed for routine paraffin embedding, and 
$3 \mu \mathrm{m}$ sections were cut and stained using haematoxylin and eosin and Gram stains.

Post mortem examinations were carried out on two patients who died of the acute infection, but tissue was not available from one necropsy that had been performed by the coroner's pathologist. Tissue retained for study from the other case included skin and subcutaneous tissue collected from the site of infection as well as heart, lung, spleen, kidney, liver, pancreas, parathyroid, coronary artery and bone, but not brain.

\section{BACTERIOLOGY}

Swabs from superficial blisters and purulent discharges were plated out on to blood agar and incubated aerobically and anaerobically at $37^{\circ} \mathrm{C}$. They were also inoculated into Todd-Hewitt broth. Excised tissue was ground up inside a safety cabinet and was both placed out on blood agar and inoculated into Todd-Hewitt broth containing $\beta$ lactamase, as tissue has been found to contain a variable amount of penicillin. This had been noticed on culture plates when streptococcal colonies only grew up away from the main pool of the inoculum of "ground up" tissue.
Subcultures of the broth were made, both aerobically and anaerobically, after incubation for one week at $37^{\circ} \mathrm{C}$. Selective agar for isolating streptococci and staphylococci, such as crystal violet or nalidixic acid and colistin (Oxoid SR70), were not found to be necessary for all specimens but were used if secondary infection of open wounds had occurred. Streptococcal colonies were identified by haemolysis and growth on bile-aesculin and blood agar and were grouped by a coagglutination method (Phadebact or Streptex): isolates were kindly M typed by $\mathrm{Dr}$ G Colman at the Division of Hospital Infection, Central Public Health Laboratory, Colindale. Staphylococcus aureus was identified by the tube coagulase test and other bacteria by standard laboratory techniques. Serial samples of serum were examined from patients with subacute necrotising fasciitis for antibodies to streptolysin $\mathbf{O}$, deoxyribonuclease $\mathbf{B}$, and hyaluronidases. $^{8}$

\section{Results}

Tables 1 and 2 show the results, together with patient details; table 3 gives the histology results.

Table 1 Cases of acute necrotising fasciitis

\begin{tabular}{|c|c|c|c|c|c|c|}
\hline Case No & Age & $\operatorname{Sex}$ & Coexisting illness & Site of lesion & Bacterial culture & Outcome \\
\hline \multicolumn{7}{|c|}{ Cases of acute necrotising fasciitis due to BHS: } \\
\hline 1 & 77 & $\mathbf{F}$ & None & Left elbow & $\begin{array}{l}\text { GpA BHS, M64 } \\
\text {-blood cultures/elbow }\end{array}$ & Died, septicaemic \\
\hline 2 & 72 & $\mathbf{M}$ & $\begin{array}{l}\text { Paraplegia due to } \\
\text { poliomyelitis }\end{array}$ & Left ankle & $\begin{array}{l}\text { GpA BHS, M22 } \\
\text {-blood cultures/ankle }\end{array}$ & Died, septicaemic \\
\hline 3 & 35 & $\mathbf{M}$ & None & Right eyelid/face & $\begin{array}{c}\text { GpA BHS, M73 } \\
\text {-blood cultures }\end{array}$ & Died, septicaemic \\
\hline 4 & 70 & $\mathbf{F}$ & COAD & Right leg & GpG BHS & Died, toxaemic \\
\hline 5 & 56 & $\mathbf{M}$ & None & Right hand/arm & $\begin{array}{l}\text { GpA BHS, M1 } \\
\text {-blister fluid/necrotic } \\
\text { tissue }\end{array}$ & Debrided and grafted \\
\hline 6 & 43 & $\mathbf{M}$ & None & Right thumb/arm & GpA BHS, M3* & Debrided and grafted \\
\hline 7 & 30 & $\mathbf{M}$ & Diabetes & Right leg & $\begin{array}{l}\text { GpA BHS, M- } \\
\text { and } S \text { aureus }\end{array}$ & Debrided \\
\hline 8 & 45 & $\mathbf{M}$ & Diabetes & Right eyelid & GpA BHS & $\begin{array}{l}\text { Debrided late and } \\
\text { grafted }\end{array}$ \\
\hline 9 & 72 & $\mathbf{F}$ & None & Left eyelid & GpA BHS, M75 & $\begin{array}{l}\text { Debrided late and } \\
\text { grafted }\end{array}$ \\
\hline 10 & 70 & $\mathbf{F}$ & None & Right index finger & GpA BHS, Ml & Amputation \\
\hline 11 & 61 & $\mathbf{F}$ & None & Left index finger & GpA BHS & Amputation \\
\hline 12 & 75 & $\mathbf{F}$ & Obese & Right leg & GpA BHS & $\begin{array}{l}\text { Debrided; died after } \\
\text { anaesthetic CVA }\end{array}$ \\
\hline 13 & 54 & $\mathbf{F}$ & None & Right thumb & GpA BHS, M1 & Debrided \\
\hline 14 & 82 & $\mathbf{F}$ & Atherosclerosis & Left leg & GpC BHS & Debrided and grafted \\
\hline 15 & 75 & $\mathbf{F}$ & Syringomyelia & Left leg & GpG BHS & Debrided \\
\hline 16 & 80 & $\mathbf{F}$ & None & Right leg & GpG BHS & Debrided and grafted \\
\hline \multicolumn{7}{|c|}{ Case of acute necrotising fasciitis and myositis due to anaerobic streptococci: } \\
\hline 17 & 65 & $\mathbf{F}$ & Diabetes & Left toe/foot & Anaerobic streptococci & Amputation \\
\hline
\end{tabular}

*BHS GpA $+S$ aureus isolated at site of injury in thumb, but pure BHS GpA isolated from spreading lesion up arm. $M-=M$ non-typable. 
Table 2 Cases of subacute necrotising fasciitis due to BHS

\begin{tabular}{|c|c|c|c|c|c|c|c|}
\hline $\begin{array}{l}\text { Case } \\
\text { No }\end{array}$ & Age & $\operatorname{Sex}$ & Coexisting illness & Site of lesion & Bacterial culture & $\begin{array}{l}\text { Haematological } \\
\text { serological } \\
\text { result }\end{array}$ & Outcome \\
\hline 1 & 69 & $\mathbf{M}$ & None & Left knee & GpA BHS & & Debrided \\
\hline 2 & 73 & $\mathbf{M}$ & None & Right foot & GpA BHS, M2 & $\mathbf{A}$ & $\begin{array}{l}\text { Eschar sloughed after } \\
5 \text { months }\end{array}$ \\
\hline 3 & 72 & $\mathbf{F}$ & Diabetes & Left thumb & GpA BHS, M64 & A & Healed with penicillin \\
\hline 4 & 74 & $\mathbf{M}$ & None & Left leg & $\begin{array}{l}\text { GpA BHS, M- } \\
\text { (blisters/blood culture) }\end{array}$ & & Healed with penicillin \\
\hline 5 & 77 & $\mathbf{M}$ & Atherosclerosis & Right foot & No growth & $\mathbf{A}$ & Debrided \\
\hline 6 & 72 & $\mathbf{F}$ & None & Right leg & $S$ aureus & A & Debrided \\
\hline 7 & 68 & $\mathbf{F}$ & None & Right foot & $S$ faecalis and Proteus $\mathbf{s p}$ & $\mathbf{A}$ & Debrided \\
\hline 8 & 41 & $\mathbf{M}$ & None & Left elbow & No growth & $\mathbf{A}$ & Incised and drained \\
\hline 9 & 22 & $\mathbf{F}$ & None & Right leg & GpA BHS and $S$ aureus & $\mathbf{A}$ & Debrided \\
\hline 10 & 49 & $\mathbf{F}$ & None & Left ankle & GpG BHS & $\mathbf{A}$ & Debrided \\
\hline 11 & 73 & F & None & Right elbow & GpA BHS, M49 & & Healed with penicillin \\
\hline 12 & 75 & $\mathbf{F}$ & Right hallux & Right foot valgus & GpC BHS & & Healed with penicillin \\
\hline 13 & 75 & $\mathbf{M}$ & None & Right leg & GpG BHS & & Debrided \\
\hline 14 & 83 & $\mathbf{F}$ & Wound sinus & Right leg & No growth & $\mathbf{C} / \mathbf{G}$ & Healed with penicillin \\
\hline 15 & 82 & $\mathbf{M}$ & None & Right thigh & $S$ aureus & A & Debrided \\
\hline 16 & 63 & $\mathbf{M}$ & None & Right thigh & $S$ aureus & $\mathbf{A}$ & Debrided \\
\hline 17 & 65 & $\mathbf{F}$ & $\begin{array}{l}\text { Systemic lupus } \\
\text { erythematosis on prednis }\end{array}$ & $\begin{array}{l}\text { Buttock } \\
\text { isone }\end{array}$ & $S$ aureus and & $\begin{array}{l}\text { A } \\
\text { Bacteroides sp }\end{array}$ & Debrided \\
\hline 18 & 77 & $\mathbf{F}$ & None & Right leg & No growth & A & $\begin{array}{l}\text { Penicillin V; healed in } \\
1 \text { month }\end{array}$ \\
\hline 19 & 63 & $\mathrm{~F}$ & None & Right arm & No growth & $\mathbf{A}$ & Debrided \\
\hline
\end{tabular}

ACUTE NECROTISING FASCIITIS (TABLE 1)

Three patients had septicaemia with growth of BHS group A in blood cultures, all of whom died. Case 1 developed the infection around the elbow while in hospital. Case 2 was admitted to hospital with necrosis around the ankle and died within 48 hours. Post-mortem examination showed that there was ante-mortem thrombus present in the subcutaneous tissue of the ankle, capillaries, and a small artery of the lung; in a vein and small artery of the heart (fig 1); and in a small artery of the spleen. Thrombus was not found in sections of liver, kidney, and pancreas, and there was no evidence of a streptococcal myositis in heart muscle. Case 3 developed erythema and oedema of the right upper eyelid spreading upwards over the forehead and scalp and downwards over the cheek, neck, and upper chest three days after his daughter poked him in the eye. Frank pus was found discharging from the conjunctiva from which Gram positive cocci were seen but failed to grow on culture. Before surgery could be undertaken he had a cardiopulmonary arrest from which spontaneous respiration never recurred.

Biopsy specimens were taken within five days after the infection had occurred. Localised areas of oedema and necrosis were found in both the dermis and epidermis; some areas showed large numbers of polymorphonuclear leucocytes invading this necrotic

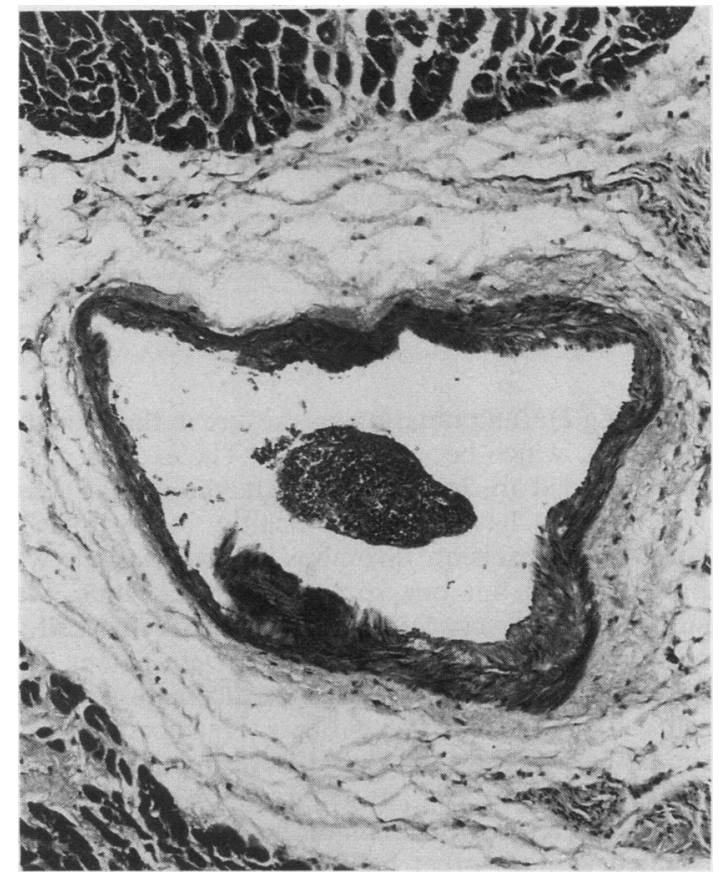

Fig 1 Thrombus in small artery of heart in disseminated intravascular coagulation due to $S$ pyogenes septicaemia (Haematoxylin and eosin.) $\times 157 \cdot 5$. 
Table 3 Histological features of streprococcal necrotising fasciitis (gangrene)

\begin{tabular}{|c|c|c|c|c|c|c|c|}
\hline \multirow[b]{2}{*}{ Case No } & \multirow[b]{2}{*}{ Epidermis } & \multicolumn{2}{|l|}{ Dermis } & \multirow[b]{2}{*}{ Subcutaneous fat } & \multicolumn{2}{|l|}{ Blood vessels } & \multirow[b]{2}{*}{ Bacteria } \\
\hline & & Superficial & Deep & & Lumen & Wall & \\
\hline \multicolumn{8}{|c|}{ Acute cases } \\
\hline 2 & Absent & $\longleftarrow$ Confluent & necrosis $\longrightarrow$ & $\begin{array}{l}\text { Necrosis and inflammation } \\
\text { (mononuclear cells, } \\
\text { neutrophils) }\end{array}$ & $\begin{array}{l}\text { Occasional } \\
\text { thrombus }\end{array}$ & $\begin{array}{l}\text { Intimal } \\
\text { thickening }\end{array}$ & $\begin{array}{l}\text { Numerous Gram posi } \\
\text { cocci in necrotic } \\
\text { dermis }\end{array}$ \\
\hline 3 & $\begin{array}{l}\text { Focal } \\
\text { necrosis }\end{array}$ & \multicolumn{3}{|c|}{ 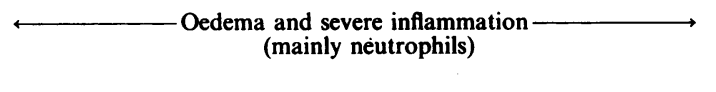 } & Patent & Normal & $\begin{array}{l}\text { Gram positive cocci } \\
\text { neutrophils and hair } \\
\text { follicles }\end{array}$ \\
\hline 5 & $\begin{array}{l}\text { Inflamed or } \\
\text { necrotic and } \\
\text { lifting off }\end{array}$ & $\begin{array}{l}\text { Confluent } \\
\text { necrosis or } \\
\text { haemorrhage } \\
\text { and inflammation }\end{array}$ & Mild inflammation & $\begin{array}{l}\text { Necrosis and severe } \\
\text { inflammation (mainly } \\
\text { neutrophils) }\end{array}$ & $\begin{array}{l}\text { Occasional } \\
\text { thrombus }\end{array}$ & Normal & Not seen \\
\hline 7 & $\begin{array}{l}\text { Inflamed or } \\
\text { necrotic and } \\
\text { lifting off }\end{array}$ & $\begin{array}{l}\text { Confluent } \\
\text { necrosis or } \\
\text { haemorrhage } \\
\text { and inflammation }\end{array}$ & \multicolumn{2}{|c|}{$\begin{array}{l}\text { Confluent necrosis } \\
\text { or inflammation } \\
\text { (mainly neutrophils) }\end{array}$} & $\begin{array}{l}\text { Thrombus in } \\
\text { inflamed or } \\
\text { necrotic } \\
\text { areas }\end{array}$ & $\begin{array}{l}\text { Intimal } \\
\text { thickening }\end{array}$ & $\begin{array}{l}\text { Numerous Gram pos } \\
\text { cocci in inflamed or } \\
\text { necrotic areas }\end{array}$ \\
\hline 10 & \multicolumn{4}{|c|}{ 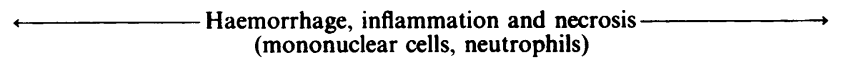 } & $\begin{array}{l}\text { Occasional } \\
\text { thrombus }\end{array}$ & $\begin{array}{l}\text { Intimal } \\
\text { thickening }\end{array}$ & Not seen \\
\hline 14 & $\begin{array}{l}\text { Confluent } \\
\text { necrosis }\end{array}$ & \multicolumn{3}{|c|}{$\stackrel{\text { Inflammation and confluent necrosis } \longrightarrow}{\text { (mainly neutrophils) }}$} & $\begin{array}{l}\text { Occasional } \\
\text { thrombus }\end{array}$ & $\begin{array}{l}\text { Intimal } \\
\text { thickening and } \\
\text { arteriosclerosis }\end{array}$ & Not seen \\
\hline 15 & \multirow[t]{2}{*}{$\longleftarrow$ Inflam } & $\begin{array}{l}\text { nmation and conflue } \\
\text { (mainly neutroph }\end{array}$ & $\begin{array}{l}\text { ent necrosis } \longrightarrow \\
\text { hils) }\end{array}$ & $\begin{array}{l}\text { Inflammation, necrosis } \\
\text { and haemorrhage } \\
\text { (mainly neutrophils) }\end{array}$ & $\begin{array}{l}\text { Occasional } \\
\text { thrombus }\end{array}$ & Normal & Not seen \\
\hline Subacute & & & & & & & \\
\hline 1 & \multirow[t]{2}{*}{$\begin{array}{l}\text { Necrotic } \\
\text { or absent }\end{array}$} & \multicolumn{3}{|c|}{$\longleftrightarrow$ Necrosis and severe inflammation $\longrightarrow$} & Patent & $\begin{array}{l}\text { Arteritis in } \\
\text { inflamed } \\
\text { areas }\end{array}$ & $\begin{array}{l}\text { Numerous Gram pos } \\
\text { cocci in fat }\end{array}$ \\
\hline 5 & & \multicolumn{3}{|c|}{-Haemorrhage and necrosis $\longrightarrow$} & $\begin{array}{l}\text { Occasional } \\
\text { recanalised } \\
\text { thrombus }\end{array}$ & $\begin{array}{l}\text { Severe intimal } \\
\text { thickening and } \\
\text { arteriosclerosis }\end{array}$ & Not seen \\
\hline 6 & Intact & $\begin{array}{l}\text { Mild } \\
\text { inflammation }\end{array}$ & 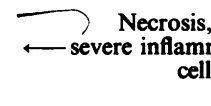 & $\begin{array}{l}\text { haemorrhage and } \\
\text { mation (mononuclear } \longrightarrow \\
\text { s, neutrophils) }\end{array}$ & Patent & $\begin{array}{l}\text { Intimal } \\
\text { thickening }\end{array}$ & Not seen \\
\hline 18 & $\begin{array}{l}\text { Necrotic } \\
\text { or absent }\end{array}$ & $\longleftarrow$ Fo & $\begin{array}{l}\text { ocal necrosis and inf } \\
\text { (mainly neutror }\end{array}$ & $\begin{array}{l}\text { lammation } \longrightarrow \text { hils) } \\
\text { om }\end{array}$ & Patent & Normal & $\begin{array}{l}\text { Numerous Gram pos } \\
\text { cocci }\end{array}$ \\
\hline
\end{tabular}

tissue (fig 2). Inflammation was severe in the subcutaneous fat, which became necrotic. The excised material extended to, but not through, the fascial layer, which would have appeared healthy at the time of surgery. Pre-excision thrombus of some vessels was present in all but one specimen, and at times was surrounded by very large numbers of Gram positive cocci (fig 3), whereas other vessels were patent. Endarteritis or arteriosclerosis and calcification of vessels was present in some patients. Haemorrhage into the tissue was found in two of seven patients.

Case 17 developed "gas gangrene" of the foot from which a pure growth of anaerobic streptococcus was isolated without other bacteria being present. Serial serology showed no evidence of infection by either BHS or $S$ aureus. She was diabetic and had suffered an interdigital foot ulcer for two weeks before hospital admission, having been treated with amoxycillin by her local doctor. Gas was present in tissues which were fully debrided on admission, when very large doses of benzyl penicillin and metronidazole were given, but the necrotising infection continued to spread through the plantar tissues of the foot so that amputation became necessary. Histology showed acute inflammation with patchy necrosis of muscle and fat. Degenerative arterial disease was present but not to an extent that could be responsible for the necrosis.

SUBACUTE NECROTISING FASCIITIS (TABLE 2) Biopsy specimens were taken 12 to 16 days after the infection had occurred, when all the patients had been treated with antibiotics. The epidermis varied between 


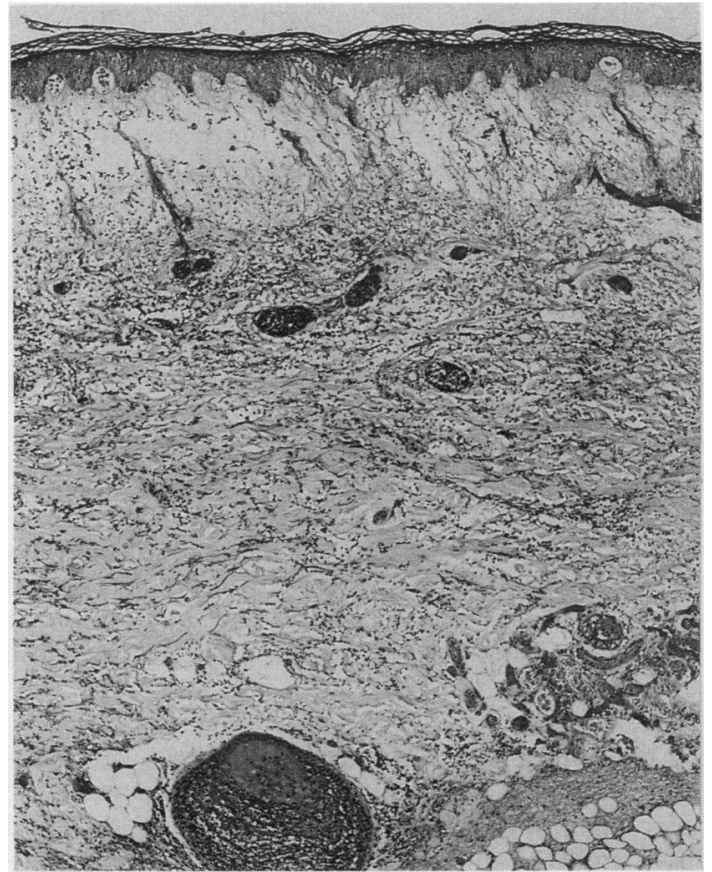

Fig 2 Oedema and impending necrosis of epidermis and dermis in acute streptococcal gangrene showing thrombosed blood vessels and large numbers of polymorphonuclear cells (Haematoxylin and eosin.) $\times 65$.

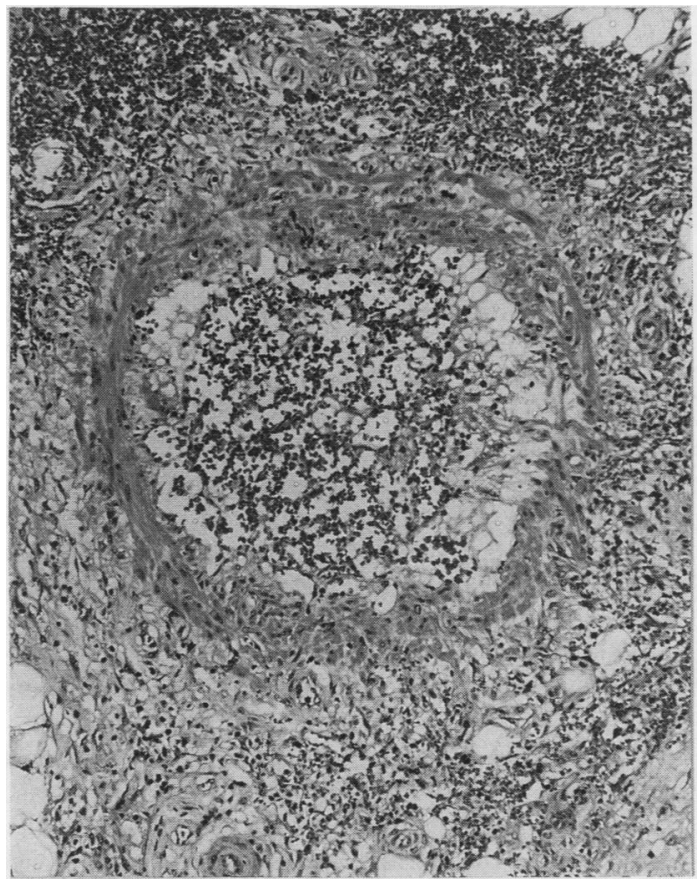

Fig 4a Thrombosed vessel in case of subacute streptococcal gangrene, surrounded by polymorphonuclear cells (Haematoxylin and eosin.) $\times 157 \cdot 5$.

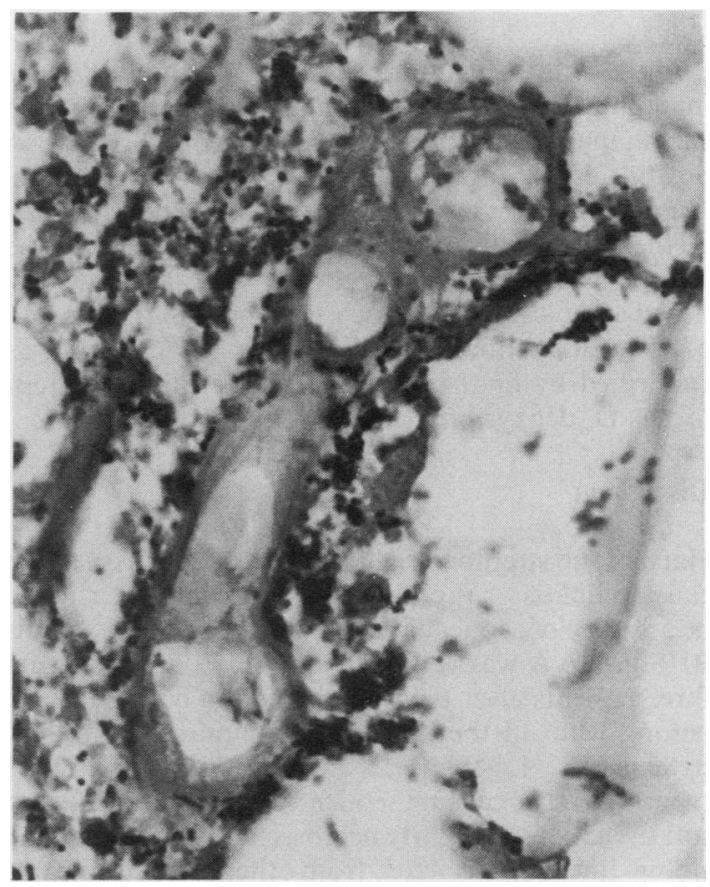

Fig 3 Large numbers of Gram positive cocci surrounding thrombosed vessels in acute streptococcal gangrene (Gram stain.) $\times 195$.

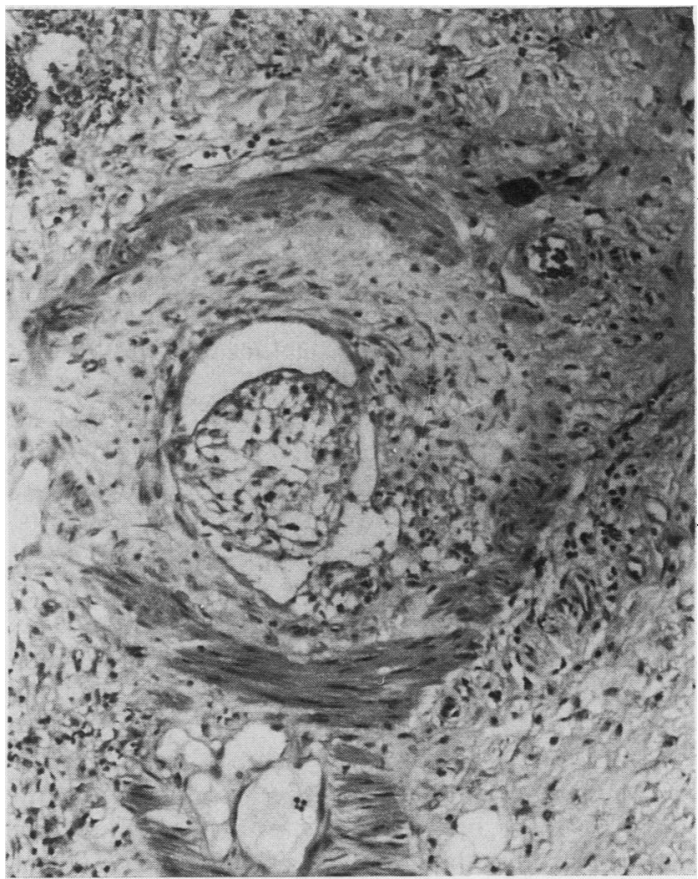

Fig 4b Recanalised vessel in case of subacute streptococcal gangrene (Haematoxylin and eosin.) $\times 157.5$. 
being healthy, acanthotic, or necrotic, but extensive inflammation was present in the lower dermis and subcutaneous fat. The presence of thrombus, Gram positive cocci, and tissue haemorrhage was variable. In one patient (case 5) there was full thickness necrosis of the dermis and much haemorrhage present in the tissues, but organisms were not seen; both thrombosed and recanalised vessels were present (figs $4 a$ and b). The differential diagnosis from an embolus was confirmed by finding rising antibody titres to streptolysis $\mathrm{O}$, deoxyribonuclease $\mathrm{B}$, and hyaluronidase.

\section{Discussion}

Haemolytic streptococcal infection of soft tissues can cause cellulitis or rapidly spreading necrosis or it can be a source of septicaemia and death. In our hospitals BHS group A was isolated from blood cultures from three patients after their death, having been collected before death in the preceding 48 hours. In the first patient (case 1, table 1), a similar BHS group A (M type 64) to that causing septicaemia was isolated from soft tissue, showing early necrosis that surrounded the elbow. It was also isolated from other patients, including case 3 (table 2), and staff in a hospital ward outbreak. $^{2}$ In the second patient (case 2) a similar BHS group A (M type 22) to that causing septicaemia was isolated from early necrosis around the ankle and also from the throat of a close relative who directly cared for him. The third patient who died had been "poked" in the eye by his daughter, who developed an area of impetigo on her face three days after her father's illness began and from which BHS group A was isolated. This infection needs to be recognised early when there is severe toxaemia. Post mortem histology has shown evidence of disseminated intravascular coagulation (DIC), which can be expected to contribute to the ensuing rapid death. Heparin was given intravenously by Graybill et al, ${ }^{10}$ together with antibiotics, and by Hammar and Wanger, ${ }^{11}$ in doses guided by activated partial thromboplastin time studies at an early stage, when they successfully treated two of eight patients with necrotising fasciitis. Haemorrhage, however, occurred in the necrotic tissues of our patients, without heparin being given, and this possibility must be considered, even though the beneficial effect of controlling the DIC over the critical septicaemic period may well be greater and permit better tissue perfusion with penicillin at sites close to the necrotic lesion.

We continued to grow BHS group A from necrotic discharging tissue five days after starting benzyl penicillin at $20 \mathrm{U} /$ day because of the failure of penicillin to penetrate through thrombosed vessels. It is thus essential to debride the infected necrotic tissue at an early stage to prevent the infection from spreading or recur- ring when antibiotics are stopped. Gangrenous tissue excised from patients infected by BHS groups $\mathrm{C}$ and $\mathrm{G}^{912}$ contained penicillin so that the degree of thrombosis caused by these strains was less than that of BHS group A: We found that granulation tissue formed rapidly after debridement, after which skin grafting was usually satisfactory. If the necrotic tissue is allowed to slough off medically it can take months to do so and be a source of reinfection. This applies particularly to subacute necrotising fasciitis where we have found severe inflammation in the dermis and subcutaneous fat with, on one occasion, recanalised thrombosed vessels. Retrograde venous flow or a collateral circulation may be mechanisms underlying the haemorrhage sometimes seen in the tissue, but ultimately necrosis occurs where there is an insufficient blood supply. In this situation cultures may be negative or misleading; better confirmation is gained by serial serological tests. ${ }^{8}$

The infections described by ourselves and Meleney ${ }^{7}$ did not spread into muscle, although they can occasionally spread between muscle bundles beneath the fascia: amputation was not generally required and debridement to the fascial layer was sufficient. Amputation of an index finger, however, was required in two patients (cases 10 and 11, table 1) where the blood vessels were extensively thrombosed. This type of infection differs from acute streptococcal rhabdomyolysis, where there is an overwhelming infection of skeletal muscle in different sites, and has so far always been fatal (Gilks CF, Lambert HP, Lansborough Jones $\mathrm{M}$, personal communication).$^{13}{ }^{14}$ It is thought to occur when there is a simultaneous picornavirus infection, causing a viral myositis and a streptococcal bacteraemia. ${ }^{15}$ BHS group A only infects skeletal muscle directly when inoculated in association with anaerobic streptococci in serious wounds when its distinction from clostridial gas gangrene must be considered. ${ }^{1617}$ Anaerobic streptococci alone, however, can infect muscle as a rare event in immunocompromised patients or diabetics (case 17, table 1), when the clinical presentation is of "gas gangrene"; anaerobic streptococci are prolific producers of hydrogen sulphide gas from muscle. A spreading necrotic process occurred in this patient that could only be halted by amputation through the ankle. As anaerobic streptococci can be difficult to grow and need to be incubated under strict anaerobic conditions for at least one week at $37^{\circ} \mathrm{C}$, they may be missed as a cause of the acutely infected diabetic foot.

Necrotising fasciitis due to BHS occurs when the organisms spread through tissue above the fascial plane, causing a thrombosis of vessels that results in gangrene of the dermis and subcutaneous fat. Meleney reported the pathological effects of streptococcal gangrene in detail in 1929 and $1933,{ }^{718}$ when surgery 


\section{Streptococcal necrotising fasciitis}

was the only form of treatment, and commented that both venules and arterioles were often found filled with thrombi but that patent blood vessels could also be present in the extensive slough supplying islands of relatively normal skin. He also noted that the infection never affected muscle or bone deep to the fascia unless injury exposed these structures. Webb et al ${ }^{19}$ commented similarly, but contrasted the histology with that of erysipelas where streptococci are found in the epidermis causing a polymorphonuclear cell infiltrate with cellular oedema and dilated blood vessels and lymphatics; lymphangitis was rarely found in necrotising fasciitis which has also been our experience. Others 112021 have noted extensive subcutaneous necrosis and collagen fragmentation with large numbers of streptococci and polymorphonuclear leucocytes in the spreading margin of the lesion. They also found that streptococci were usually absent from more superficial tissues and that skin in the area of "blue patches" was necrotic but nearby skin could be only congested. These effects result in the variable clinical features of patchy dusky discolouration of skin and blistering alongside normal and gangrenous skin with no clear distinguishing margin between them. The histological features are also variable but depend as well on the site and depth of tissue biopsied. Common features for both the acute and subacute types include severe inflammation of the dermis and subcutaneous fat with patchy necrosis and tissue haemorrhage. While occasional thrombus was usually found in vessels from the acute type, biopsied within five days, vessels in the subacute type were patent or recanalised-but had been biopsied one week later. The lesion is best studied with multiple sections taken from the spreading edge right through the necrotic tissue. Whether streptococci can be found depends on the site biopsied and the stage of the infection; in late stages evidence of streptococcal infection may only be available from specific serology.

We are grateful to Mr D Kingston and Dr K Rogers for their advice and to Dr G Colman for typing our strains of $S$ pyogenes and for serological tests.

\section{References}

1 Aitken DR, Mackett T, Smith LL. The changing pattern of hae- molytic streptococcal gangrene. Arch Surg 1982;117:561-7.

2 Seal DV, Leppard B. Necrotizing fasciitis - a disease of temperate and warm climates. Trans $R$ Soc Trop Med 1982;76:392-5.

3 Guiliano A, Lewis F, Hadley K, Blaisdell FW. Bacteriology of necrotizing fasciitis. Am $J$ Surg 1977;134:52-7.

4 Reid RI, Briggs RS, Seal DV, Pearson AD. Virulent Streptococcus pyogenes: outbreak and spread within a geriatric unit. $J$ Infect 1983;6:219-25.

5 Redding PJ. Streptococcus pyogenes infection. Br Med J 1980;281:1639.

6 Cruickshank JG, Hart RJC, George M, Feest TG. Fatal streptococcal septicaemia. Br Med J 1980;282:1944.

7 Meleney FL. A differential diagnosis between certain types of infectious gangrene of the skin. Surg Gynecol Obstet 1933;56:847-67.

8 Leppard BJ, Seal DV. The value of bacteriology and serology in the diagnosis of necrotizing fasciitis. $\mathrm{Br} J$ Dermatol 1983;109:37-44.

9 Gaunt N, Rogers K, Seal D, Denham M, Lewis J. Necrotizing fasciitis due to group $\mathbf{C}$ and $\mathbf{G}$ haemolytic streptococci after chiropody. Lancet 1984;i:516.

10 Graybill JR, Pierson DN, Charache P. Tissue antibiotic penetration in streptococcal gangrene. John Hopkins Med J 1973;133:45-50.

11 Hammar $\mathrm{H}$. Wanger L. Erysipelas and necrotizing fasciitis. $\mathrm{Br} \mathrm{J}$ Dermatol 1977;96:409-19.

12 Seal D, Stephenson M, Welch A, Leppard B, Colman G, Hallas G. Comparison of necrotizing fasciitis due to groups A, C \& G haemolytic streptococci and its reproduction in an animal model. In: Kimura Y, Kotani S, Shiokawa S, eds. Recent advances in streptococci and streptococcal diseases. Bracknell: Reedbooks Ltd, 1985:360-1.

13 MacLennan JD. Streptococcal infection of muscle. Lancet 1943;i:582-4.

14 Barrett AM, Gresham GA. Acute streptococcal myositis. Lancet 1958;i:347-51.

15 Porter CB, Hinthorn DR, Couchonnal G. et al. Simultaneous Streptococcus and Picornavirus infection-muscle involvement in acute rhabdomyolysis. JAMA 1981;245:1545-7.

16 MacLennan JD. Anaerobic infections of war wounds. Lancet 1943;ii:63-6; 94-9; 123-6.

17 Hayward NJ, Pilcher R. Anaerobic streptococcal myositis. Lancet 1945;ii:560-2.

18 Meleney FL. Haemolytic streptococcus gangrene; the importance of early diagnosis and early operation. JAMA 1929;92:2009-12.

19 Webb HEW, Hoover NW, Nichols DR, Weed LA. Streptococcal gangrene. Arch Surg 1962;85:969-73.

20 Strasberg SM, Silver MS. Haemolytic streptococcus gangrene: an uncommon but frequently fatal infection in the antibiotic era. Am J Surg 1968;115:763-8.

21 Bahna M, Canalis RF. Necrotizing fasciitis (streptococcal gangrene) of the face. Arch Otolargngol 1980;106:648-51.

Requests for reprints to: Dr DV Seal, Division of Communicable Diseases, Clinical Research Centre, Watford Road, Harrow, Middlesex HAl 3UJ, England. 